\title{
SIRT7 wt Allele
}

National Cancer Institute

\section{Source}

National Cancer Institute. SIRT7 wt Allele. NCI Thesaurus. Code C102771.

Human SIRT 7 wild-type allele is located in the vicinity of $17 q 25$ and is approximately $6 \mathrm{~kb}$ in length. This allele, which encodes NAD-dependent protein deacetylase sirtuin-7 protein, is involved in the modulation of protein acetylation. 